\title{
Discursive Textual Analysis of Brazil's National Curricular Guidelines for Youth and Adult Education: Meanings and Senses
}

\author{
Romilda Teodora Ens, Marciele Stiegler Ribas, Elizabeth Dantas de Amorim Favoreto \\ Pontifical Catholic University of Paraná, Curitiba, Brazil \\ Email: romilda.ens@gmail.com, marci.stiegler.ribas@gmail.com, elizabethfavoreto@hotmail.com
}

Received 16 June 2016; accepted 8 August 2016; published 11 August 2016

Copyright $(\subset 2016$ by authors and Scientific Research Publishing Inc.

This work is licensed under the Creative Commons Attribution International License (CC BY).

http://creativecommons.org/licenses/by/4.0/

(c) (i) Open Access

\begin{abstract}
Youth and Adult Education (EJA) faces great challenges in the beginning of the 21st century. Among its basic issues, it can be highlighted the need to specific teachers' professional and education policies. Regarding Brazil, since 1996 its educational system is ruled by the National Education Guidelines and Framework Law (LDBN No. 9394/1996) which included Youth and Adult Education as a specific type of Basic Education. Many studies have been developed since then, debating about the appropriate adult-teacher learning approach towards students in a wide age-range, stressing their singularities in meaningful contexts. Our study aims to analyze the National Curricular Guidelines for Youth and Adult Education applying the discursive textual analysis methodology path in order to interpret and understand the meanings and senses of this type of educational phenomenon. We will also evaluate the goals of its proposal for teachers' work outlined in the text content of this policy. The significance of our studies is to provide new understandings and contributions for further policy making that may address the peculiarities and singularities in the field of teacher education for Youth and Adult Education (EJA) target audience.
\end{abstract}

\section{Keywords}

Youth and Adult Education, Teacher Education, Discursive Textual Analysis

\section{Introduction}

In face of the great challenge to discuss Youth and Adult Education (EJA) in Brazil we set ourselves the challenge to analyze the National Curricular Guidelines for this type of Basic Education in Brazil. According to Article 37 of the National Education Guidelines and Framework Law (Brazil, 1996) the students [...] who did not 
have access to or were not able to conclude their studies in elementary and secondary education levels of Basic Education at the appropriate age, that is, 15 years of age for elementary 18 for secondary, can attend a specific type of Basic Education (EJA) and get a diploma that could guarantee basic preparation for work and citizenship as any other student who has completed the regular three levels of Basic Education.

Although the Federal Constitution of 1988 states that it is the State's duty to offer compulsory and public Basic Education for citizens from birth to 17 years old, there is considerably high demand for EJA in Brazil. As an alternative to solve this problem, the Federal Constitution also endure [...] its gratuity to those who did not have access to it at the proper age (Brazil, 1988), due to the promise to end illiteracy in 93\% of the population which remains unfulfilled, given the number of illiterate people over 15 years of age-approximately 13.2 million people according to School Census Basic Education data (Brazil, 2014). Another frightening issue concerns the growing evasion in this type of Basic Education is justified by different personal or professional reasons which led these students end up dropping out or being expelled by the school.

Table 1 shows the decline of EJA students' enrollment rates by the period covering from 2007 to 2013 (-4.4\% in elementary stage and $-1.6 \%$ in secondary stage). This result is based on data from School Census of Basic Education, methodology developed by the National Institute for Educational Studies and Research "Anísio Teixeira” (Brazil, 2014).

In Table 1, we can observe that the number of EJA students has declined year-over-year, despite the increasing enrollment rate in other regular levels of Basic Education. According to some researches on this field of study, it is due to various issues, such as adverse socioeconomic conditions, early entry into the workforce, lack of school infrastructure, and inadequate teacher education specific for EJA. Although, we have to consider that teachers' unpreparedness to work in EJA is not the only reason which contributes to the rise in this evasion. Such listed matters show the contradiction that supports the idea that State policy actions can intervene directly in the social reality by establishing links with society just through policies. According to Bonetti (2006) that happens if a political fact generates public policies that fulfill common interest in order to meet the needs and requirements from social segments.

\section{Youth and Adult Education Public Policy}

Considering the fact that the State cannot be considered as a neutral agent, such intentional impartiality must be analyzed carefully because it might overlook the conflictive dynamic that emerges from the various interests of various social agents (Bonetti, 2006). Given that such interests have undergone changes along history according to the battle for power in various segments of society, when we analyze Adult and Young Education through its policies, it is essential to take into account the pressure of the regulatory market that, according to Bonetti (2006: p. 40), imposes the idea of compared advantage, in which all segments of society have access to conditions that correspond to [...] homogeneous rules of supply and demand as equals.

So as to match the assumption of homogeneity based on the liberal theory, it becomes obvious to claim for universal access to Basic Education for all Brazilians in order to certify the completion of obligatory universal schooling, in response to the requirements imposed by the world of labor. Indeed, minimum schooling standards did not follow such universalization concerns.

Table 1. Number of EJA students' enrollment rates (2007-2013).

\begin{tabular}{cccc}
\hline & \multicolumn{2}{c}{ EJA students' enrollment rates in Basic Education } & \\
\hline Year & Elementary & Secondary & Total \\
2007 & 3.367 .032 & 1.618 .306 & 4.985 .338 \\
2008 & 3.295 .240 & 1.650 .184 & 4.945 .424 \\
2009 & 3.094 .524 & 1.566 .808 & 4.661 .332 \\
2010 & 2.860 .230 & 1.427 .004 & 4.287 .234 \\
2011 & 2.681 .776 & 1.364 .393 & 4.046 .169 \\
2012 & 2.561 .013 & 1.345 .864 & 3.906 .877 \\
2013 & 2.447 .792 & 1.324 .878 & 3.772 .670 \\
\hline
\end{tabular}

Source: INEP data bank (Brazil, 2013). 
To this end, the National Curricular Guidelines for Youth and Adult Education (Brazil, 2000) was introduced into Brazil educational system in 2000 and outlined a regulatory curriculum framework in order to standardize and regulate teachers' pedagogical practice for this type of Basic Education, considering social and cultural diversity of EJA students.

In order to understand how these guidelines deal with teacher education for EJA type and address the peculiarities and singularities to teachers' work, we first analyzed the education scenario of EJA in Brazil. In the second part, we presented the methodological path for developing the grounds of discursive textual analysis proposed by Moraes \& Galiazzi (2006).

\section{Method}

For this research, we selected the National Curricular Guidelines for Youth and Adult Education as a text corpus to apply discursive textual analysis as a methodological path to develop a qualitative descriptive and interpretative documentary study in order to understand how this policy configures this type of education and teaching phenomena for Youth and Adult Education (EJA) in Brazilian context.

Due to methodological rigor in seeking new insights into a holistic understanding of the phenomenon which may emerge in a documentary research, Moraes \& Galiazzi (2006) claims that analyzing a document based on discursive textual analysis approach would enable the researchers to build new meanings and senses by interpreting the explicit or implicit words of other voices that may emerge from the text.

\section{Discursive Textual Analysis}

Discursive textual analysis is a methodological path described by Moraes (2003) and Moraes \& Galiazzi (2006) as a cycling movement provide different ways to analysis the text corpus, involving the following three specific steps: unitization, categorization and self-organization. For each approach, it is necessary to develop steps containing distinct and complementary cyclical analysis stages creating a sequence of [...] coming and going, grouping and ungrouping, building and deconstructing (Moraes \& Galiazzi, 2006: p. 122) towards a construction of relations, capturing what is new and emerging about the phenomenon analyzed.

To better illustrate this entire process, Moraes (2003) compares it to a thunderstorm by describing it as a continuous cycle in a permanent hermeneutic movement in the quest to fully understand the phenomenon. That is, throughout the process, it is possible to see flashlights that indicate different interpretations and understandings of the phenomenon being studied.

In Table 2, we explain the continuous cycling analysis movement proposed for each step according to Textual discursive analysis methodological approach.

The first step is called, by Moraes (2003), unitization. This step refers to the process of text corpus fragmentation into sense units, which involves careful reading and careful processes that enables the researcher unravel the text in units of signifiers that may be implicit or explicit in the text corpus. According to Moraes (2003; 2006), for this step the researcher has to develop a coding process that includes the rewriting and designation of each unit as an element of meaning to the phenomenon. After the fragmentation of the text corpus into sense units, the researcher assigns a keyword to identify each of them in order to facilitate the establishment of relationships and grouping categories.

After the selection of the sense units in the process of unitization, the researcher proceeds to the categorization step, which provides the establishment of relations between these sense units and the categories formation. According to Moraes \& Galiazzi (2006), the categorization process could occur from pre-existing categories or

\section{Table 2. Discursive textual analysis approach.}

\begin{tabular}{ll}
\hline Approach & Cycle movement \\
Unitization & $\begin{array}{l}\text { Break up the text corpus into meaningful sense units. Name each unit using keywords that } \\
\text { could represent it. }\end{array}$ \\
Categorization & $\begin{array}{l}\text { Group the sense units into categories and sub-categories which will be explained based on } \\
\text { and theoretical framework and empirical studies. } \\
\text { Create a descriptive-interpretative new text (metatext) taking account on the emerged } \\
\text { categories bringing up new understandings of the phenomen studied in order to make it } \\
\text { as comprehensible as possible to the reader. }\end{array}$ \\
\hline
\end{tabular}


emerging ones that come out from the textual analysis. According to Moraes (2003), the categories features must require relevant, valid and homogeneous standards based on principle and common concepts. The relevance and validity of these categories are related to the theories that underlie the studies and researches in the fields of Young people and Adults Education (EJA) and also in the teacher education for this Basic Education type.

The last step of the continuous cycling analysis movement, proposed by Textual Discursive Analysis (Moraes, 2003) is the creation of a new reflexive text (metatext) as a result of a deconstruction and self-organization process of the material analyzed in the search for new understandings of the phenomenon studied throughout an empiric and theoretical combination, which emerge as a result of the “[...] analytical process, reaching new forms of new order through chaos and disorder (Moraes, 2003: p. 210).

\section{Results and Discussion}

After the process of National Curricular Guidelines for Youth and Adult Education text unitization, we arranged the text corpus into three different, but complementary categories: EJA public target; EJA teacher education and EJA curriculum framework which was subdivided in two subcategories (content and assessment). Even though our analysis focuses on teacher education for this Basic education type, we consider it important to present the remaining categories, as they have direct impact on the formation of this kind of teacher. In Table 3, we present the categories and subcategories emerged from the categorization process.

Following the breakdown of these categories and subcategories, we moved to the third step with the drafting of the metatext articulating empirical and theoretical arguments, which aimed to describe and interpret the "sense and meaning” built in a cycling moving dialogue with the previous steps (Moraes, 2003).

\section{Metatext}

The analysis of each of its categories - and respective subcategories_-indicate the following assumptions:

1) EJA public target: EJA education is designed for people who have not concluded their studies at the age deemed appropriate by law. Therefore, the National Curricular Guidelines for Youth and Adult Education determine that enrollment of children and adolescents aged 15 or below is prohibited, including emancipated minors. As to the identity of EJA, three principles are highlighted: neutrality, difference and proportionality. Neutrality concerns education equality in order to promote the right to education. Regarding difference, two connotations stand out, the first one recognizes that EJA students have different characteristics that need to be addressed in the education process, and the second one highlights the appreciation of the merits of each student. From this perspective, I understand that the specificities that are present in EJA are recognized by the Guidelines; however, each student is responsible for their own success or failure. This feature is characteristic of the meritocratic model that arises from a neoliberal policy, which blames the individual for their failure or success. In this sense, [...] students who fail are no longer seen as victims of social injustice, but rather as individuals who are responsible for their failure, because the school gave them, a priori, every chance to succeed like the others (Dubet, 2004: p. 543).

2) EJA curriculum framework:

a) As stated by Pacheco (2003: p. 15), [...] curriculum texts that come from the central administration are work documents that symbolize the State's official discourse, which gathers various interests and alliances developed at different levels of action. In this subcategory, we have identified a certain dichotomy. On one side EJA's specificities are recognized in the text by having EJA's own identity set, and on the other side, the National Curricular Guidelines for Elementary and Secondary Basic Education regular levels is prescribed as a

Table 3. Categories and subcategories emerged.

\begin{tabular}{cc} 
Categories & Sub-categories \\
\hline EJA public target & - \\
EJA curriculum framework & content \\
EJA teacher education & assessment \\
\hline
\end{tabular}


curriculum reference for Youth and Adult Education (EJA). Although we understand that the contents to be covered in EJA should be correspond to the ones from elementary and secondary Basic Education regular levels, it would be necessary to revise such guidelines in order to adapt them to the specificities of EJA education. In relation to the level that corresponds to the elementary level, there is a certain "infantilization" of contents and activities for EJA's students as a result of poor teacher education to work in this type of education. That is, many teachers simply replicate children elementary content and pedagogical approach to EJA classes. One must consider that EJA students have rich backgrounds and bring knowledge that was learnt in informal education, in their life experience, in the relationship with their peers. Therefore, as mentioned by Gadotti (2011: p. 47), they [...] cannot be treated like a child whose life story is just beginning. They want to see the immediate application of what is learnt.

That said, it appears that the guidelines feature the notion of an adapted curriculum, one that is not exclusive to EJA, which has led to a lack of identity in this type of Basic Education. Although it mentions neutrality, difference, and proportionality, by analyzing the need to consider EJA's specificities, its curriculum base consists of a series of improvisations and adaptations resulting in a hybridization of the curriculum frameworks developed for regular elementary and secondary levels of Basic Education. Once more, the success of this type of education and even students' success is placed under the teachers' responsibility even though they have not had a specific teacher education for working in EJA pedagogical context.

b) Assessment: It concerns to different forms of assessment and subsequent certification, through equivalence exams, from the other Basic Education levels. Schools are to prepare such assessments following the skills required by the guidelines. In this subcategory, we would like to highlight the fragmented nature of assessments in such equivalence exams ${ }^{1}$ to obtain the diplomas or certificate for elementary and secondary Basic Education levels in EJA. By analyzing how the assessment is structured and organized in this type of education, it is important to state the main certification purpose, expressed in EJA's quickened process. Such quickened process explains the [...] compensatory vision that grants to Youth and Adult Education (EJA) the mere function of replacing schooling that was missed during childhood or adolescence (Di Pierro, 2006: p. 20).

3) EJA teacher education: The lack of specific teacher education to work in EJA, many researchers have been discussed this matter, such as Arroyo, 2006, Capucho, 2012 and Ens \& Ribas, 2015. They have described the lack of public policies that enhance the importance of teacher education that considers the contexts of those students. However, the National Curricular Guidelines for Basic Education Teacher Education deals with teaching matters for this type of education in Article 17, by stating that initial and on-going teacher education will be based on the National Curricular Guidelines for Elementary and Secondary Basic Education regular levels, it does not require specific teaching strategies to face singular characteristics, conditions, and space and time requirements related to EJA teaching and learning process. To summarize, as argued by Arroyo (2006: p. 18): In other words, it is possible to say that if there are no clear policies for teacher education in EJA, that is because there are no clear policies for EJA, and he goes on to say that such policies need to be built, and this process will require a lot of initiative and creative skills to be done. In my opinion, that will demand a great deal of dialogue, a great deal of clarity in the discussion of teacher education courses, in order to include a specific training for EJA's target public. While public policies deal with this issue superficially, the lack of motivation and high level of student's evasion in EJA demands a wide discussion among educational professionals, researchers and policy makers in order to offer a solid teacher education focused on the peculiarities of these students.

\section{Conclusion}

In summary, after analyzing the National Curriculum Guidelines for Youth and Adult Education based on discursive textual analysis approach, we could interpret and understand that teacher education for EJA is not well outlined in this legal document. The interconnection of the categories emerged (EJA: public target, curriculum framework and teacher education) offered us key elements for the creation of a metatext in a self-organized process that has provided a space for the reconstruction of meanings and senses that emerged in our analysis of the EJA teacher education phenomenon. We highlight strictly compensatory vision of EJA educational proposals in Brazil and, therefore, the vision that EJA is merely a path for certification. The undervaluation of EJA, denounced by Haddad and Di Pierro (2000), can also be seen in teacher education policy, an area that is dealt very superficially and also restates the precarious and quickness of EJA teacher education process, thus compromising

\footnotetext{
${ }^{1}$ Another way of obtaining an elementary or secondary Basic Education degree is studying on their own and taking online test.
} 
teachers' commitment and idealization when working with EJA students. In this situation, the State takes on a regulatory and assessing role, while education becomes the teachers’ exclusive responsibility (Ens \& Gisi, 2011).

\section{References}

Arroyo, M. G. (2006). Formar educadores e educadoras de jovens e adultos. In L. Soares (Ed.), Formação de educadores de jovens e adultos [Youth and Adult Educators Training] (pp. 17-32). Belo Horizonte: Autêntica.

Bonetti, L. W. (2006). Políticas públicas por dentro [Inside Public Policies]. Ijuí, SP: Unijuí.

Brazil (1988). Constituição da república federativa do Brasil [Federal ConstitutionofBrazil]. Texto promulgado em 05 de outubro de 1988. Brasília, DF: Senado federal: Secretaria especial de editoração e publicações: Subsecretaria de edições técnicas.

Brazil (1996). Lei $n^{\circ}$ 9.394, de 20 de dezembro de 1996. Estabelece as diretrizes e bases da educação nacional [Law $n^{\circ}$. 9394, 20. December 1996. Estabilishthenationaleducationguidelinesand framework]. Diário oficial da união, Brasília, DF, 23 dez. 1996.

Brazil (2000). Resolução CNE/CEB $n^{\circ} 1$, de 05 de julho de 2000. Estabelece as diretrizes curriculares nacionais para a educação de jovens e adultos [Resolution CNE/CEB $n^{\circ}$.1, 05.July 2000. Estabilishthe National Curricular Guidelines for Youth and Adult Education]. Diário oficial da união, Brasília, DF, 19 July 2000, Seção I, p. 18.

Brazil (2013). INEP. Sinopses estatísticas da educação básica [INEP. Statistic Synopes Education Basic]. http://portal.inep.gov.br/basica-censo-escolar-sinopse-sinopse

Brazil (2014). INEP. Censo escolar da educação básica 2013: resumo técnico [Basic educationschoolcensus 2013: technicalsummary]. Instituto Nacional de Estudos e Pesquisas Educacionais Anísio Teixeira. Brasília, DF: O Instituto.

Brazil (2014). IBGE. Pesquisa Nacional por Amostra de Domicílios [IBGE. Home National Data Research]. Dados do IBGE de 2014, considerando todas as faixas etárias. http://www.ibge.gov.br/home/

Capucho, V. (2012). Educação de jovens e adultos: Prática pedagógica e fortalecimento da cidadania. [Youth and Adult Education: Pedagogical Practice and Citizenship Strength]. São Paulo: Cortez.

Di Pierro, M. C. (2006). Um balanço da evolução recente da educação de jovens e adultos no Brasil. In: Construção coletiva: contribuições à educação de jovens e adultos [Collective Construction: Contributions to Youth and Adult Education] (pp. 17-30). Brasília: UNESCO, MEC, RAAAB.

Dubet, F. (2004). O que é uma escola justa? [What Is a Fair School?]. Cadernos de Pesquisa [Research Journal], 34, 539555. http://dx.doi.org/10.1590/S0100-15742004000300002

Ens, R. T., \& Gisi, M. L. (2011). Políticas educacionais no Brasil e a formação de professores. In R. T. Ens, \& M. A. Behrens (Eds.), Políticas de formação do professor: caminhos e perspectivas [Teacher Training: Paths and Perspectives] (pp. 25-50). Curitiba: Champagnat.

Ens, R. T., \& Ribas, M. S. (2015). Formação de professores para a educação de jovens e adultos: uma análise das diretrizes curriculares. Práxis Educativa [Educational Praxis], 10, 127-152. http://dx.doi.org/10.5212/PraxEduc.v.10i1.0006

Gadotti, M. (2011). Educação de jovens e adultos: Correntes e tendências. In M. Gadotti, \& J. E. Romão (Eds.), Educação de jovens e adultos: Teoria, prática e proposta [Youth and Adult Education: Theories, Practice and Proposals] (pp. 35-47). São Paulo: Cortez.

Haddad, S., \& Di Pierro, M. C. (2000). Escolarização de jovens e adultos. Revista Brasileira de Educação [Brazilian Education Journal], 13, 108-130.

Moraes, R. (2003). Uma tempestade de luz: A compreensão possibilitada pela análise textual discursiva. Ciência \& Educação [Science \& Education], 9, 191-211. http://dx.doi.org/10.1590/s1516-73132003000200004

Moraes, R., \& Galliazzi, M. C. (2006). Análise textual discursiva: processo reconstrutivo de múltiplas faces. Ciência \& Educação [Science \& Education], 12, 117-128. http://dx.doi.org/10.1590/s1516-73132006000100009

Pacheco, J. A. (2003). Políticas curriculares: Referenciais para a análise [Curricular Policies: Analysis Benchmarks]. Porto Alegre: Artmed. 